\title{
Germplasm Evaluation of Soyabean (Glycine max L.) through Morphological and Quality Characterization
}

\author{
Rajbeer Singh Gaur and Ayodhya P. Pandey* \\ Department of Genetics and Plant Breeding, Faculty of Agriculture Science \\ AKS, University, Satna 485001 (M.P.), India \\ *Corresponding author
}

\begin{tabular}{|l|}
\hline Ke y w o r d s \\
Soybean, \\
PPV\&FRA act, \\
$\begin{array}{l}\text { Candidate varieties, } \\
\text { Characterization }\end{array}$ \\
\hline Article Info \\
$\begin{array}{l}\text { Accepted: } \\
10 \text { July } 2020 \\
\text { Available Online: } \\
10 \text { August } 2020\end{array}$ \\
\hline
\end{tabular}

\author{
A B S T R A C T
}

Soybean (Glysine max L.) a important oil seed crop has been characterized previously on various aspects through DUS (distinctiveness, uniformity and stability) test. In this study an attempt is being made to characterized 10 popular varieties of soybean at agriculture research farm of AKS University Satna under natural environment as per the guidelines of The Protection of Plant Varieties and Farmer Right Authority (PPV\&FRA 2009). The varieties were characterized for 13 characters viz. plant growth type, days to $50 \%$ flowering, leaf shape, leaf colour, plant growth habit, flower colour, plant height, pod colour, pod shattering, days to maturity, seed index, seed shape and seed colour. Most of the varieties have medium height except JS 9560 and JS 2034 were short type and JS 9752, NRC 99 and NRC86 were tall. Most of the varieties have plant growth type semideterminate and indeterminate except JS 9560 was determinate. Most of the varieties have leaf shape pointed ovate except JS 9560 and JS9305 were lanceolate and NRC 117 and NRC 99 were rounded ovate. Most of the varieties have plant growth habit semi-erect except JS 2069, JS 2034 and JS 335 were erect. All candidate varieties showed purple flower colour whereas JS 2069, JS 2034, JS 2029 and JS 9752 have white flower colour. Most of the varieties have medium maturity duration except JS 9560, JS 9305 and JS 2034 were early maturing type.

\section{Introduction}

Soybean (Glycine max L. Merril) $(2 \mathrm{n}=40)$ is the world's most important seed legume native to East Asia, which contributes to $25 \%$ of the global edible oil, about two-thirds of the world's protein concentrate for livestock feeding. Soybean meal is a valuable ingredient in formulated feeds for poultry and fish. It is very important oil seed crop in India and is called as a golden bean or miracle bean because of its versatile nutritional qualities having $20 \%$ oil and 38 to 43 percent protein, which has biological value as meat and fish protein and rich in amino acids like lysine and tryptophan (Quayam et al., 1985). Soybean is ranked number one in international market among world's major oilseed crops (Chung \& Singh 2008). Total 51 soybean improved varieties have been notified/ released in India 
for the cultivation in different agro-ecological zones of the country during 2005 to 2018 (National Food Security Mission). The distinctness, uniformity and stability are to be established by the DUS Test. Therefore candidate varieties are to be compared with all the varieties, whose existence is matter of common knowledge and with the most similar varieties. Characterization of varieties is important in order to avoid the duplication varieties are classified on the basis of morphological and seed characters. Qualitative characters are being more stable over generations (Raut, 2003) hence are reliable for characterization of varieties. For yield improvement, it is essential to have knowledge on the variability of different characters such as days to $50 \%$ flowering, days to maturity, plant height $(\mathrm{cm})$, number of branches/plant, number of pods/plant, number of seeds/plant, 1000-seed weight $(\mathrm{g})$, seed yield per plant $(\mathrm{g})$, biological yield $(\mathrm{g})$, and harvest index (\%). Morphological traits can be used to assess phenotypic variation in growing environments and are also used as tools for the indirect analysis of genetic variability and diversity (Kaur et al., 2016). Genetic variability is the basic requirement for crop improvement as this provides wider scope for selection.

Knowledge of diversity patterns will allow breeders to better understand the evolutionary relationships among accessions, to sample germplasm in a more systematic fashion and to develop strategies to incorporate useful diversity in their breeding programs (Naik et al., 2016). The information on genetic diversity helps in choosing parents for generation of new varieties, needs of continuous evaluation of germplasm for useful characters, which in earlier days was solely based on the available morphological data. Morphological traits/markers reflect not only on the genetic composition of the cultivar, but also the interaction of the genotype with the environment in which it is expressed (Shadakshari et al., 2011). Therefore, the present study was planned to characterize the 10 soybean varieties for 13 different traits.

\section{Materials and Methods}

10 varieties of soybean, 7 obtained from JNKVV Jabalpur JS 2069, JS9560. JS9305, JS 2034, JS 2029, JS 335, JS 9752 and three varieties from Directorate of Soybean Research Indore was NRC 117, NRC 86, NRC 99. Characterization of seed was done in 2017. All 10 varieties were planted in the experimental field of AKS University Satna during Kharif, 2017. Varieties were planted in eight rows in five meter row length $(45 \times 10$ $\mathrm{cm})$. Characterization was done for 13 different characters at different stages of crop growth as per DUS test guidelines (PPV\& FRA, 2009). Data were recorded on randomly selected fifteen competitive plants. Correlation was studied between the traits like days to $50 \%$ flowering, plant height, days to maturity, and seed index by karl Pearson's correlation method.

\section{Results and Discussion}

In the present study, 9 qualitative and four quantitative traits were studied for establishing the varietal distinctness. All the 13 characters were found to be polymorphic in nature (table 1 and 2). Submitted seed samples were characterized for seed characteristics. Six varieties were with small seed size one (JS 95-60) was with large seed size, one(JS 93-05) was with small seed size and rest were with medium seed size. Growth habit was determinate (JS 95-60, JS 335) and semi-determinate (JS 20-69, JS93-05, JS 2034, JS 20-29, JS 97-52, NRC 117, NRC 86, NRC 99). Leaf color was green in most of the varieties except JS 9560, JS 9305 JS 335 and NRC 86 have dark green leaf color. 
Table.1 Qualitative characters and their state of expression

\begin{tabular}{|c|c|c|c|c|c|c|c|c|c|}
\hline Varieties & $\begin{array}{c}\text { Plant: } \\
\text { Growth } \\
\text { type }\end{array}$ & $\begin{array}{l}\text { Leaf: } \\
\text { Shape }\end{array}$ & $\begin{array}{l}\text { Leaf: } \\
\text { Colour }\end{array}$ & $\begin{array}{c}\text { Plant } \\
\text { growth } \\
\text { habit }\end{array}$ & $\begin{array}{l}\text { Flower: } \\
\text { Colour }\end{array}$ & $\begin{array}{l}\text { Pod: } \\
\text { colour }\end{array}$ & $\begin{array}{c}\text { Pod: } \\
\text { shattering }\end{array}$ & $\begin{array}{l}\text { Seed: } \\
\text { shape }\end{array}$ & $\begin{array}{l}\text { Seed } \\
\text { colour }\end{array}$ \\
\hline JS 20-69 & $\begin{array}{c}\text { semi- } \\
\text { determinate }\end{array}$ & $\begin{array}{l}\text { Pointed } \\
\text { ovate }\end{array}$ & Green & Erect & White & Yellow & $\begin{array}{c}\text { Non- } \\
\text { shattering }\end{array}$ & Elliptical & Yellow \\
\hline JS 95-60 & Determinate & Lanceolate & $\begin{array}{l}\text { Dark } \\
\text { green }\end{array}$ & Erect & Purple & Brown & $\begin{array}{c}\text { Non- } \\
\text { shattering }\end{array}$ & Spherical & Yellow \\
\hline JS 93-05 & $\begin{array}{c}\text { semi- } \\
\text { determinate }\end{array}$ & $\begin{array}{l}\text { Pointed } \\
\text { ovate }\end{array}$ & $\begin{array}{l}\text { Dark } \\
\text { green }\end{array}$ & $\begin{array}{l}\text { Semi- } \\
\text { erect }\end{array}$ & Purple & Brown & $\begin{array}{c}\text { Non- } \\
\text { shattering }\end{array}$ & Elliptical & Yellow \\
\hline JS 20-34 & $\begin{array}{c}\text { semi- } \\
\text { determinate }\end{array}$ & $\begin{array}{c}\text { Pointed } \\
\text { ovate }\end{array}$ & Green & $\begin{array}{l}\text { Semi- } \\
\text { erect }\end{array}$ & White & Brown & $\begin{array}{c}\text { Non- } \\
\text { shattering }\end{array}$ & Spherical & Yellow \\
\hline JS 20-29 & $\begin{array}{c}\text { semi- } \\
\text { determinate }\end{array}$ & $\begin{array}{c}\text { Pointed } \\
\text { ovate }\end{array}$ & Green & $\begin{array}{l}\text { Semi- } \\
\text { erect }\end{array}$ & White & Yellow & Shattering & Elliptical & Yellow \\
\hline JS 335 & Determinate & $\begin{array}{l}\text { Pointed } \\
\text { ovate }\end{array}$ & $\begin{array}{l}\text { Dark } \\
\text { green }\end{array}$ & $\begin{array}{l}\text { Semi- } \\
\text { erect }\end{array}$ & Purple & Yellow & $\begin{array}{c}\text { Non- } \\
\text { shattering }\end{array}$ & Elliptical & Yellow \\
\hline $\begin{array}{c}\text { NRC } \\
117\end{array}$ & $\begin{array}{c}\text { semi- } \\
\text { determinate }\end{array}$ & $\begin{array}{c}\text { Rounded } \\
\text { ovate }\end{array}$ & Green & $\begin{array}{l}\text { Semi- } \\
\text { erect }\end{array}$ & Purple & Yellow & $\begin{array}{c}\text { Non- } \\
\text { shattering }\end{array}$ & Elliptical & Yellow \\
\hline NRC 86 & $\begin{array}{c}\text { semi- } \\
\text { determinate }\end{array}$ & $\begin{array}{c}\text { Pointed } \\
\text { ovate }\end{array}$ & $\begin{array}{l}\text { Dark } \\
\text { green }\end{array}$ & $\begin{array}{l}\text { Semi- } \\
\text { erect }\end{array}$ & Purple & Yellow & $\begin{array}{c}\text { Non- } \\
\text { shattering }\end{array}$ & Elliptical & Yellow \\
\hline NRC99 & $\begin{array}{c}\text { semi- } \\
\text { determinate }\end{array}$ & $\begin{array}{l}\text { Rounded } \\
\text { ovate }\end{array}$ & Green & $\begin{array}{l}\text { Semi- } \\
\text { erect }\end{array}$ & Purple & Yellow & $\begin{array}{c}\text { Non- } \\
\text { shattering }\end{array}$ & Elliptical & Yellow \\
\hline JS 97-52 & $\begin{array}{c}\text { semi- } \\
\text { determinate }\end{array}$ & $\begin{array}{l}\text { Pointed } \\
\text { ovate }\end{array}$ & Green & $\begin{array}{l}\text { Semi- } \\
\text { erect }\end{array}$ & White & Yellow & $\begin{array}{c}\text { Non- } \\
\text { shattering }\end{array}$ & Elliptical & Yellow \\
\hline
\end{tabular}


Table.2 Quantitative characters and their state of expression

\begin{tabular}{|c|c|c|c|c|}
\hline Varieties & Days to 50\% flowering & Plant height $(\mathbf{c m})$ & Days to maturity & Seed index (gm.) \\
\hline JS 20-69 & Late & Medium & Late & Medium \\
\hline JS 95-60 & Medium & Short & Early & Large \\
\hline JS 93-05 & Late & Medium & Early & Small \\
\hline JS 20-34 & Medium & Short & Early & Medium \\
\hline JS 20-29 & Late & Medium & Medium & Medium \\
\hline JS 335 & Late & Tall & Late & Medium \\
\hline NRC 117 & Late & Tall & Late & Medium \\
\hline NRC 86 & Late & Tall & Medium & Medium \\
\hline NRC99 & Late & Tall & Late & Medium \\
\hline JS 97-52 & Late & Tall & Late & Medium \\
\hline
\end{tabular}

1. Plant: days to $50 \%$ flowering; Early $\leq 35$ days, Medium $36-45$ days, Late $>45$ days

2. Plant: height; Short $\leq 40 \mathrm{~cm}$, Medium $41-60 \mathrm{~cm}$, Tall $>60 \mathrm{~cm}$.

3. Plant: days to maturity; Early $\leq 95$ days, Medium 96-105 days, Late $>105$ days.

4. Seed: size; Small $\leq 10 \mathrm{~g}$, Medium 10.1- $13.0 \mathrm{~g}$, Large $>13.0 \mathrm{~g}$.

Table.3 Mean and range of quantitative traits

\begin{tabular}{|c|c|c|c|}
\hline Characters & Mean & $\begin{array}{c}\text { Standard } \\
\text { Deviation }\end{array}$ & Range \\
\hline Days to 50\% flowering & 50.00 & 5.946 & $38.00(J S ~ 20-34)$ to 60.00(JS 97-52) \\
\hline Plant height (cm) & 56.65 & 20.316 & $38.00($ JS 95-60) to 73.00(JS 97-52) \\
\hline Days to maturity & 103.8 & 35.023 & $80.00($ JS 95-60) to 130.00(JS 97-52) \\
\hline Seed index (gm.) & 11.24 & 3.913 & $8.72($ JS 93-05) to 14.52(JS 95-60) \\
\hline
\end{tabular}




\section{Correlation Matrix}

\begin{tabular}{|c|c|c|c|c|}
\hline Character & $\begin{array}{c}\text { Days to 50\% } \\
\text { flowering }\end{array}$ & $\begin{array}{c}\text { Plant height } \\
\text { (cm) }\end{array}$ & $\begin{array}{c}\text { Days to } \\
\text { maturity }\end{array}$ & $\begin{array}{c}\text { Seed index } \\
\text { (gm.) }\end{array}$ \\
\hline Days to 50\% flowering & $\mathbf{1 . 0 0 0}$ & $0.799 * *$ & $0.8204 * *$ & -0.27 \\
\hline Plant height (cm) & & $\mathbf{1 . 0 0 0}$ & $0.721^{*}$ & -0.14 \\
\hline Days to maturity & & & $\mathbf{1 . 0 0 0}$ & -0.143 \\
\hline Seed index (gm.) & & & & $\mathbf{1 . 0 0 0}$ \\
\hline
\end{tabular}

* Correlation is significant at the 0.05 level

** Correlation is significant at the 0.01 level

Days to 50\% flowering is positively correlated with Plant height and Days to maturity at the 0.01 level . Plant height is positively correlated with Days to maturity at the 0.05 level. Seed index (gm.) is negatively correlated between Days to 50\% flowering, Plant height and Days to maturity.

Graph.1 Days to 50\% Flowering vis-a-vis Days to Maturity

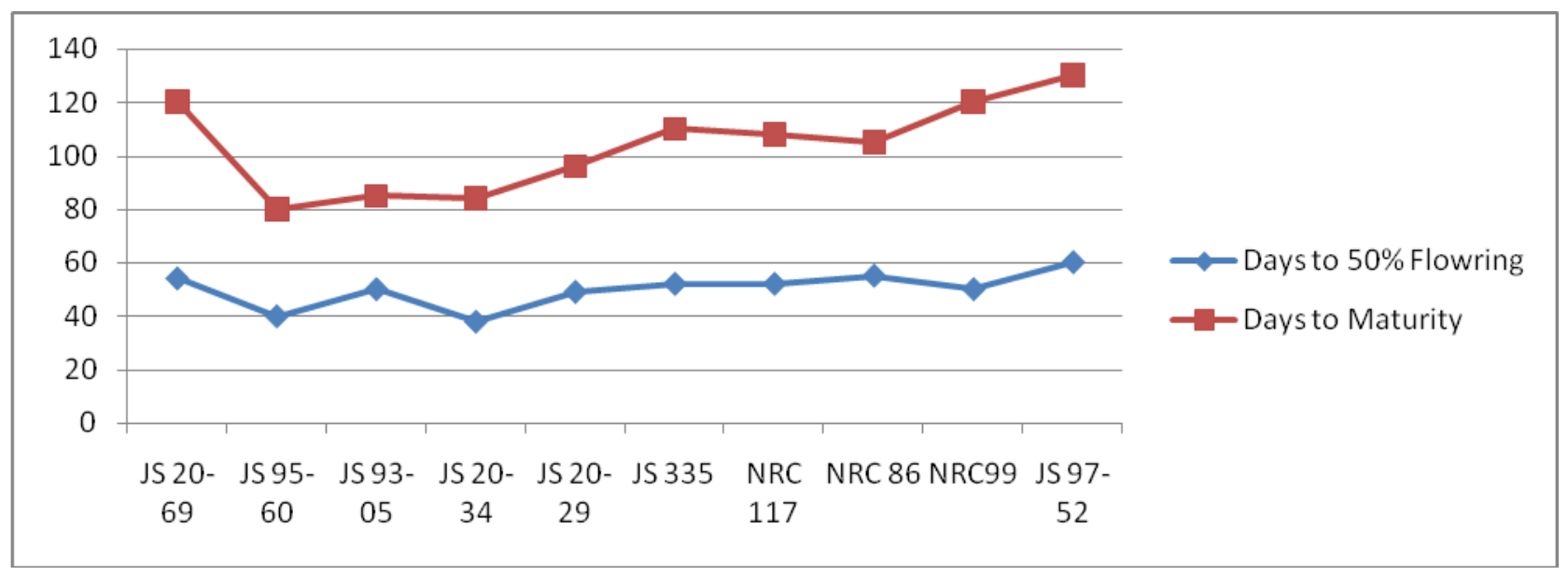

Days to $50 \%$ flowering and days to maturity exhibited a significant Positive correlation (0.8204) 
Two groups of flower color, white and purple were observed. All varieties except JS 20-69, JS 20-34, JS 20-29 and JS 97-52 were purple flower colored. All three groups of plant height i.e. short (JS 95-60, JS 20-34), medium (JS 20-69, JS 93-05, JS 20-29) and tall (JS 335, NRC 117, NRC86, NRC99, JS 97-52) were observed. It ranged from $73.00 \mathrm{~cm}$ (JS97-52) to $38.00 \mathrm{~cm}$ (JS 95-60). Pod color was brown in JS 95-60, JS 93-05 and JS 2034 , rest others were yellow pod colored. All varieties were resistant to pod shattering except JS 20-29. Seed shape of all the varieties was generally elliptical except JS 9560 and JS 20-34. All the varieties were with dull appearance and yellow to yellow green seed color. Days to $50 \%$ flowering ranged from 38 days (JS 20-34) to 60 days (JS 97-52) but days to maturity were early ranged from 80 days (JS 95-60) to 130 (JS 97-52) days. Positive significant correlation was found between days to $50 \%$ flowering and plant height (0.799), days to $50 \%$ flowering and days to maturity (0.8204) and between plant height and days to maturity (0.721). Whereas, highly non significant negative correlation was found between Days to $50 \%$ flowering and Seed index (gm.), Plant height $(\mathrm{cm})$ and Seed index (gm.), Days to maturity and Seed index (gm.) (table 4). It is concluded that out of 10 soybean varieties were characterized and found distinct to each other. Thus in the present study morphological descriptors proved to be more helpful as the identity of all the cultivar could be established individually.

\section{References}

Anonymous. 2009. Guidelines for the conduct of test for distinctiveness, uniformity and stability on soybean (Glycine max (L.) Merril). Plant Variety Journal of India 3(10): 13-22.

GRIN. Germplasm Resources Information Network. [cited 28 February 2018] Database: GRIN [Internet] Available from: https://www.ars-grin.gov/
Gupta A, Mahajan V, Khati P and Srivastava A K. 2010. Distinctness in Indian soybean (Glycine max) varieties using DUS characters. Indian Journal of Agricultural Sciences 80 (12): 1081-4

Kaur, G., Joshi, A., Jain, D. Choudhary, R. and Vyas, D. 2016. Diversity analysis of green gram (Vigna radiata (L.) Wilczek) through morphological and molecular markers. Turkish Journal of Agriculture and Forestry, 40: 229-240.

Naik, S.M., Madhusudan, K., Motagi1, B.N. and Nadaf, H.L. 2016. Diversity in Soybean (Glycine max) Accessions Based on Morphological Characterization and Seed Longevity Characteristics. Thimmaraju1 Progressive Research - An International Journal, 11(3): 377-381.

Ramteke R, Kumar V, Murlidharan P and Agarwal DK. 2010. Study on genetic variability and traits interrelationship among released soybean varieties of India [Glycine max (L) Merril]. Electronic Journal of Plant Breeding 1(6): 1483-7

Ramteke R and Murlidharan P. 2012 Characterization of Soybean (Glycine max) varieties as per DUS Guidelines. Indian Journal of Agricultural Sciences 82(7): 572-7.

Ross J. Arkansas soybean research studies 2015. Available from: http://arkansasagnews.uark.edu /pdf/637.pdf.

Shadakshari, T.V., Kalaimagal, T., Senthil, N., Boranayaka, M.B., Kambe Gowda, R. and Rajesha, G. 2011. Genetic diversity studies in soybean [Glycine $\max$ (L.) Merrill] based on morphological characters. Asian Journal of Bio Science, 6(1): 7-11.

Satyavathi CT, Bharadwaj CH, Hussain SM, Karmarkar PG, Tiwari SP, Joshi OP and Mohan Y. 2004. Identification key for soybean (Glycine max) varieties released or notified in india. Indian Journal of Agricultural Sciences 74: 215-8. 


\section{How to cite this article:}

Rajbeer Singh Gaur and Ayodhya P. Pandey. 2020. Germplasm Evaluation of Soyabean (Glycine $\max$ L.) through Morphological and Quality Characterization. Int.J.Curr.Microbiol.App.Sci. 9(08): 09-15. doi: https://doi.org/10.20546/ijcmas.2020.908.002 